The University of Maine

\title{
DigitalCommons@UMaine
}

Earth Science Faculty Scholarship

Earth Sciences

1984

\section{Frost-Free Record Reconstruction for Eastern Massachusetts, 1733-1980}

William R. Baron

Geoffrey A. Gordon

Harold W. Borns Jr.

University of Maine - Main, borns@maine.edu

David C. Smith

Follow this and additional works at: https://digitalcommons.library.umaine.edu/ers_facpub Part of the Earth Sciences Commons

\section{Repository Citation}

Baron, William R.; Gordon, Geoffrey A.; Borns, Harold W. Jr.; and Smith, David C., "Frost-Free Record Reconstruction for Eastern Massachusetts, 1733-1980" (1984). Earth Science Faculty Scholarship. 160.

https://digitalcommons.library.umaine.edu/ers_facpub/160 


\title{
NOTES
}

\section{Frost-Free Record Reconstruction for Eastern Massachusetts, 1733-1980}

\author{
William R. Baron, Geoffrey A. Gordon, HaRold W. BORNS, JR., AND DaVid C. SMITH \\ Institute for Quaternary Studies, University of Maine, Orono, ME 04469
}

12 October 1982 and 25 October 1983

\begin{abstract}
A reconstruction methodology utilizing such varied documents as diaries, agricultural journals, U.S. Weather Bureau killing frost records and instrumental records is discussed. A resultant 248-year frost record for eastern Massachusetts exhibits marked variations in the length of the growing season, that occur on a time scale of approximately 70 years. There is an apparent systematic long-term relationship between the timing of spring and fall killing frosts and the last 100 years of record reveals a decline in year-to-year variability.
\end{abstract}

\section{Introduction}

The reconstruction of long climate records from historical materials has contributed much to our understanding of preinstrumental climatic episodes. However, there is a need for reconstructions of different climatic parameters, particularly those with agricultural significance (National Research Council, 1976). One such parameter, for which there is considerable historical data available, is the frost-free season. Analysis of numerous personal diaries and agricultural journals kept for New England locations during the eighteenth and nineteenth centuries permits the reconstruction of long term frost-free season series for the area. The longest of these reconstructions is one for eastern Massachusetts covering the period from 1733 through 1980 for an area within a 40 kilometer radius of Boston.

\section{The record}

The reconstruction of a long frost series presents a number of methodological problems. These include determining the precise meteorological meaning of the term "killing frost", combining and homogenizing instrumental records and diary materials from disparate sources and reconstructing a series representative of a geographical region rather than the more common practice of assembling frost-free season records for a fixed location. The use of historical records has predetermined the solutions to all of these problems.

The term "killing frost" was one that was used by U.S. Weather Bureau observers from 1870 to 1948 and referred to frost that killed $50 \%$ or more of the annual vegetation. The frost-free season was a period of time from the last killing frost in the spring to the first killing frost in the fall.

Different plant species have differing tolerances to low temperatures and so, since 1948 , frost data has been reported using temperature levels such as $0^{\circ} \mathrm{C}$.
Recently, a number of other threshold temperatures have been suggested (Brinkmann, 1979). The data to reconstruct the frost-free records described here are based on the killing frost concept. For the period 17731869,42 diaries and agricultural journals were used. All references to frost were extracted along with descriptions of the extent of frost damage and types of crops impacted. Frost kill reports on maize and potatoes were separated from the rest. Where no frost kill dates on these crops for a particular year could be located within the study area, kill dates on various vegetable vines such as watermelons and cucumbers were utilized. By differentiating between types of crops reported as damaged, it is possible to determine the minimum temperature necessary to produce that damage. This information is obtained by reference to research on crop resistance to frost. Corn and potatoes in their fruiting stage are harmed at temperatures of $-1^{\circ} \mathrm{C}$ through $-3^{\circ} \mathrm{C}$, while melons and cucumbers are damaged at $0^{\circ} \mathrm{C}$ to $-1{ }^{\circ} \mathrm{C}$ (Chang, 1968).

After 1870 , U.S. Weather Bureau observers continued the record of killing frost observations. Examination of late nineteenth century field records, available through the National Archives (1815-92), shows that killing frost observations were based on the same crops as the previous period. The use of these key crops probably did not change through the first half of the twentieth century as they remained important in the area. The killing frost record for the period 1880-1920 was contrasted with last and first occurrences of $0^{\circ} \mathrm{C}$ and found to be comparable to within an average of one or two days. Therefore, the record from 1948 to the present was reconstructed using $0^{\circ} \mathrm{C}$ as the threshold temperature. Comparison of the pre- 1870 frost series with instrumental records was attempted, but results proved problematical because long run, homogeneous instrumental records could not be found. The use of unreliable maximum and minimum ther- 
mometers (Middleton, 1966) in addition to nonstandardized observation times contributed to the heterogeneity of many pre-1870 instrumental records (Mitchell, 1958; Shaal and Dale, 1977).

\section{Reconstruction methodology}

The decision to reconstruct a frost series for a region as opposed to a fixed location was prompted by two considerations. First, there was no long-running source of frost data available for any single location within the study area. However, there are usually several frost records available for any given year. The second factor was the desire to produce a record that was representative of a large area, thus negating localized influences as much as possible.

For each year frost reports from several locations were compared. Late or early killing frost reports from specific locations were often unsubstantiated by reports from other localities. Eventually the frost dates from a number of locations clustered around a 2-3 day period. The mean date of this cluster was determined to be the last or first killing frost date for the region during that particular growing season. This procedure discounted the impact of localized radiation frosts, reconstructing the series instead on the first and last occurrences of a killing frost on a regional basis. The resulting estimate is conservative in the sense that any error involved in using averages of clustered dates will contribute to a longer growing season length than would be obtained by using an individual record. Research by Rosenberg and Meyers (1962) has shown that at a given location there may be between two and five local frosts after the last widespread frost in the spring and between one and three local frosts before the first widespread frost in the fall. The occurrences of localized frosts in our data are consistent with their conclusions.

\section{Results}

Figure 1 shows our reconstruction of first and last frost dates with a superimposed 20-year running mean and Table 1 shows means and standard deviation statistics reported by decade. One of the most striking characteristics of the series is the inverse relationship, correlation -0.331 (significant at 99\%) between the timing of the last and first killing frosts. When frosts occur late in the spring they also tend to occur earlier in the fall. This systematic relationship appears at a dominant time scale of 70 years and is evidence of warming and cooling temperature trends operating in the same direction during concurrent spring and fall seasons.

The length of the frost-free season has changed over time. During the eighteenth century the mean length of the frost-free season was 144 days with extremes of 80 days and 239 days. The mean last and first frost dates were 8 May and 29 September with extremes of

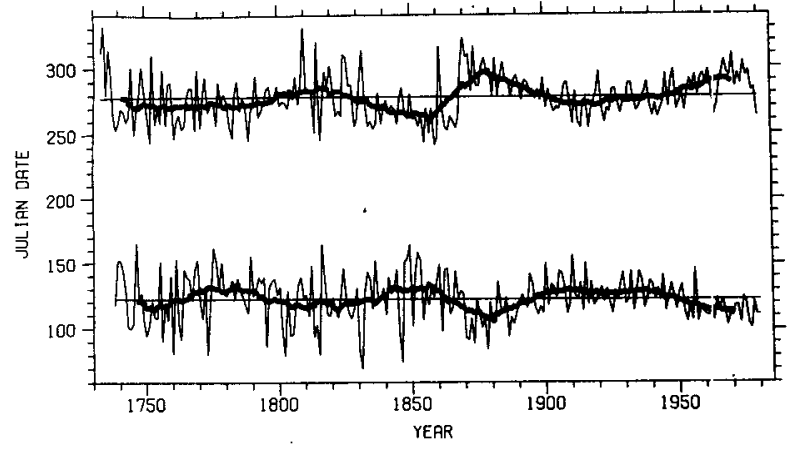

FIG. 1. Eastern Massachusetts first and last frost dates, 1733-1980, and 20-year running means.

11 March, 14 June and 29 August, 17 November, respectively. During the nineteenth century, the mean length of the season increased by 14 days. The last spring frost was earlier, around 30 April, while the fall frost was later, on 5 October. The mean frost-free season for the present century is two days longer than its predecessor, with the frost dates falling on 2 May and 6 October on average.

A change in the variability of the growing season is as important for agriculture, if not more important, than a decrease in the mean length of the growing season. A comparison of standard deviation statistics by decade and century shows a decline in seasonal variability during the eighteenth century from a high, in the $1740 \mathrm{~s}$, of 36 days to a low, in the $1790 \mathrm{~s}$, of 17 days. The nineteenth century was dominated by two decades of high variability, the 1810 s and the 1860 s. However, taken as a whole, there was a gradual decrease in variability to the twentieth century, where levels are between 15 and 18 days. The variability of spring and fall killing frost dates was similar to that described for the frost-free season as a whole.

\section{Discussion}

To test for regional representativeness, we compared the eastern Massachusetts frost series to a number of other frost series for other regions (Davis, 1972; Brown, 1976; Moran and Morgan, 1977; Lamb, 1977; Thom and Shaw, 1958). These other series show the frostfree season becoming shorter while the Massachusetts record is growing progressively longer. Reconstructed frost records for five other New England areas (the Merrimac Valley in New Hampshire, south-roastal Maine, northern Maine, the Connecticut River Valley in Massachusetts, and northern Vermont) compare favorably with the eastern Massachusetts record until the $1930 \mathrm{~s}$. Thereafter, they show a progressive decline in the length of the frost-free season. Because these other five records represent areas not affected by increased urbanization, we believe the eastern Massachusetts record, after 1935, may be influenced by the 
TABLE 1. Decadal means and standard deviations in days for eastern Massachusetts frost dates.

\begin{tabular}{|c|c|c|c|c|c|c|c|c|c|c|c|}
\hline Decade & $00 \mathrm{~s}$ & $10 \mathrm{~s}$ & $20 \mathrm{~s}$ & $30 \mathrm{~s}$ & $40 \mathrm{~s}$ & $50 \mathrm{~s}$ & $60 s$ & $70 \mathrm{~s}$ & $80 \mathrm{~s}$ & $90 \mathrm{~s}$ & Century \\
\hline \multicolumn{12}{|l|}{ 18th Century } \\
\hline Mean & - & - & - & 126 & 156 & 160 & 137 & 145 & 138 & 148 & 144 \\
\hline Standard deviation & - & - & - & 28 & 36 & 30 & 31 & 27 & 22 & 17 & 27 \\
\hline \multicolumn{12}{|l|}{ 19th Century } \\
\hline Mean & 169 & 164 & 162 & 148 & 142 & 121 & 152 & 195 & 195 & 177 & 154 \\
\hline Standard deviation & 22 & 42 & 27 & 34 & 31 & 22 & 42 & 15 & 8 & 21 & 26 \\
\hline \multicolumn{12}{|l|}{ 20th Century } \\
\hline Mean & 144 & 141 & 148 & 148 & 150 & 167 & 175 & 177 & - & - & 156 \\
\hline Standard deviation & 19 & 16 & 14 & 15 & 18 & 18 & 17 & 16 & - & - & 17 \\
\hline
\end{tabular}

urban heat island effect (Lamb, 1972; Washington, 1972).

Examination of seasonal (spring, MAM; summer, JJA; and autumn, SON) temperature series for Boston does reveal an increase of approximately $1^{\circ} \mathrm{C}$ in mean summer temperatures between the periods 1896-1930 and 1931-78. Clear trends were not apparent for the spring and fall seasons. The factors influencing the frost-free season since 1935 are difficult to determine and the increase probably should not be attributed to a single cause. It is important to note in this regard that the frost record contains other increases of similar magnitude and that the timing of the autumn frost has taken a definite turn toward earlier dates since 1970.

Supplemental New England frost records also were used to validate the precipitous rise and fall of the Massachusetts record between 1850 and 1900 . There was some concern that this portion of the record might not be homogeneous because of the change in 1870 from diary and journal data to U.S. Weather Bureau records. However, our other five series, which were reconstructed by using differing record combinations, confirm that the lengthening and shortening of the frost-free season during the last half of the nineteenth century is not due to a heterogeneous record.

\section{Summary and conclusion}

The frost record for eastern Massachusetts shows evidence of low-frequency climatic variation on a time scale of 70 years. In addition, there is a systematic relationship between last and first frost dates and a change in year-to-year variability over the past 100 years that is reflected in a decline of decadal standard deviations. The record also demonstrates a possible impact of urbanization on the incidence of frost in a given area.
Acknowledgments. We thank C. Bliss, A. Bridges and $\mathrm{J}$. TeBrake for technical assistance and their comments on the manuscript and B. J. Keller of the Laboratory of Tree-Ring Research, University of Arizona, for her assistance in preparation of graphs. Support was provided by the Climate Dynamics Program of the National Science Foundation under Grants ATM 7908415, ATM 8019514 and ATM 8115714.

\section{REFERENCES}

Brinkmann, W. A. R., 1979: Growing season length as a indicator of climatic variations. Climatic Change, 2, 128-129.

Brown, J. A., 1976: Shortening of growing season in the U.S. corn belt. Nature, 260, 420-421.

Chang, J., 1968: Climate and Agriculture. Aldinen, p. 101.

Davis, N. E., 1972: The variability of the onset of spring in Britain. Quart. J. Roy. Meteor. Soc., 98, 765-767.

Lamb, H. H., 1972: Climate Present, Past, and Future, Vol. I. Methuen, 517-519.

- 1977: Climate Present, Past, and Future, Vol. 2. Methuen, 477.

Middleton, W. E. K., 1966: A History of the Thermometer. Johns Hopkins Press, 153-161.

Mitchell, J. M., Jr., 1958: Effect of changing observation time on mean temperature. Bull. Amer. Meteor. Soc., 39, 83-89.

Moran, J. M., and M. D. Morgan, 1977: Recent trends in hemispheric temperature and growing season indices in Wisconsin. Agric. Meteor., 18, 2-5.

National Research Council, 1976: Climate and Food. National Academy of Science, p. 19.

Rosenberg, N. J., and R. E. Meyers, 1962: The nature of growing season frosts in and along the Platte Valley of Nebraska. Mon. Wea. Rev., 90, 471-476.

Shaal, L. A., and R. F. Dale, 1977: Time of observation bias and "climate change". J. Appl. Meteor., 16, 215-222.

Thom, H. C. S., and R. H. Shaw, 1958: Climatological analysis of freeze data for Iowa. Mon. Wea. Rev., 86, 151-155.

Washington, W. M., 1972: Numerical climatic-change experiments: The effects of man's production of thermal energy. $J$. Appl. Meteor., 11, 768-772. 